\title{
The Effect of Authentic Leadership on Organizational Citizenship Behaviors Mediated by Trust in Leaders
}

\author{
Ria Wahyuni*, \& Agoes Ganesha Rahyuda \\ Faculty of Economics and Business Udayana University, Bali, Indonesia
}

* riawahyuni041@gmail.com

\begin{tabular}{|c|c|}
\hline Article Info & Abstract \\
\hline Received : 2021-04-12 & The purpose of this study was to analyze the effect of authentic \\
\hline Accepted : 2021-07-09 & leadership on OCB mediated by trust in leaders at Royal Tulip \\
\hline Published : 2021-07-30 & Springhill Resort Jimbaran. This research was conducted at the \\
\hline $\begin{array}{l}\text { Key words: authentic } \\
\text { leadership, trust in leaders, } \\
\text { organizational citizenship } \\
\text { behaviors }\end{array}$ & $\begin{array}{l}\text { was } 65 \text { employees using nonprobability sampling with saturated } \\
\text { sampling technique. The data were analyzed using path analysis } \\
\text { techniques. Collecting data through interviews and distributing } \\
\text { questionnaires. The results showed that authentic leadership had a } \\
\text { positive and significant effect on OCB at the Royal Tulip Springhill } \\
\text { Resort Jimbaran. Authentic leadership has a significant positive } \\
\text { effect on trust in leaders of Royal Tulip Springhill Resort Jimbaran. } \\
\text { Trust in leaders have a significant positive effect on OCB at Royal } \\
\text { Tulip Springhill Resort Jimbaran. Trust in leaders partially mediate } \\
\text { the influence of authentic leadership on OCB at Royal Tulip } \\
\text { Springhill Resort Jimbaran. The implication of this research is that } \\
\text { with the existence of trust in leaders, authentic leadership can have } \\
\text { an effect on OCB. Therefore, with better authentic leadership, trust } \\
\text { in leaders will increase and will also increase employee OCB. }\end{array}$ \\
\hline
\end{tabular}

\section{INTRODUCTION}

Royal Tulip Springhill Resort Jimbaran is one of the players in the accommodation service industry on the island of Bali. The hotel offers a variety of hotel rooms with interesting views, especially in Bali. This hotel is one of the well-known hotels in Indonesia with an investment business and hotel management including, luxury villas, resorts, and spas, and restaurants within the hotel. To compete in the intense competition in this industry, Royal Tulip Springhill Resort Jimbaran certainly requires high-performing employees who can demonstrate citizenship behavior in their organization. Based on initial interviews with three employees in the housekeeping section, two employees in the room service section, two kitchen staff, and hotel HRM, it was found that authentic leadership, trust in leaders were not optimal. The authentic leadership that is implemented is not optimal, seen from the less open leader does not understand his followers, such as when decisions are made by leaders without discussing it with their followers, which makes trust in leaders less. So that followers agree and do work forced and not based on trust in leaders, this will cause employees not to show their OCB attitude; they will only work according to what has been ordered.

The problem of organizational citizenship behavior, there are several facts where there is a negative performance that has an impact on decreasing the performance of the hotel, such as employees who arrive late, do not attend meetings, and violate established rules and complain about the assignment given. In addition, some employees only carry out their duties and responsibilities, do not desire to help colleagues who have heavier workloads, and have a low sense of concern for colleagues who need help. These behaviors are actions that do not support effectiveness at work. If they are ignored, they will reduce the ability of Royal Tulip Springhill Resort Jimbaran to compete in the accommodation service industry on the island of Bali. 
Organ (1997) described organizational citizenship behavior as the commitment and contribution of a person in the maintenance and enhancement of social and psychological contexts that provide support for task performance in organizations. The OCB construct can be organized into seven dimensions which include helping behavior, sportsmanship, organizational loyalty, obedience, individual initiative, civic virtue, and self-development (Podsakoff et al., 2000). OCB is optional-voluntary behavior; It is not part of the official job requirements, but exceeds the expectations of required performance and appears in various behaviors such as helping others, volunteering in additional work, and avoiding unnecessary conflicts in organizations (Shin et al., 2017). If employees have an understanding of the importance of having an OCB perspective, the employees will get benefits, such as increased team cohesiveness, productivity, and organizational performance (Bambale, 2014).

Peus et al. (2012) found that authentic leadership can be seen as a predictor of OCB. Bhindi et al. (2008) explained authentic leadership as a type of leadership whose leaders highly uphold moral and ethical values with the aim of improving their followers and themselves. Avolio \& Walumbwa (2014) stated that authentic leaders inspire and motivate subordinates and have a strong interpersonal orientation. Authentic leadership shows its authenticity and is able to foster respect, credibility, and trust among employees (Bamford et al., 2013). Leaders who exhibit a balanced process also spend time trying to understand what causes problems and outcomes, thereby helping followers understand what should be attributed to the internal and external causes of ethical behavior and performance (Gardner et al., 2005). When leaders are able to understand followers by building positive relationships, followers will have a sense of responsibility for the success of their organization by improving organizational performance and being able to reflect OCB's attitude.

Authentic leadership represents one of the modern expectations in leadership, and is founded on the moral side of leader behavior and is built on trust between leaders and followers, which in turn increases creativity and innovation in organizations (Sosik \& Jung, 2018). The theory that supports this statement is the theory of social exchange Blau (1964) hich revolves around the principle of reciprocity in which one party provides services to the other party, and the other party develops a sense of obligation to reciprocate (Kashyap \& Rangnekar, 2014). Tonkin (2013) conducted research on software companies in the United States, found that there was a positive correlation between the four dimensions of the authentic leadership dimension and OCB using job satisfaction as a mediator. Yeşilkaya \& Aydın (2016) also found a positive and significant relationship between perceived authentic leadership and OCB in the Turkish public sector. The results showed that authentic leadership has a positive effect on follower characteristics such as employee citizenship behavior or OCB.

Gardner et al. (2005) argued that authentic leadership focuses on forming authentic relationships between leaders and followers that are characterized by trust and integrity. Trust in leaders can be considered as one of the most significant factors that mediate leadership effectiveness towards OCB (Podsakoff et al., 2000). Authentic leaders also care about their followers and have a high level of integrity and credibility. All of these attributes and behaviors can help authentic leaders to build follower trust (Agote et al., 2016). Authentic leaders can gain trust when they build positive relationships with followers. Because authentic leaders care deeply about their followers and are always open, followers will believe in the actions taken by the leader and improve their performance for the success of the organization. This is supported by social exchange theory, in which Fung et al. (2012) stated that social exchange theory is the view of employees when they have been treated well by the organization, they will tend to behave and behave more positively towards the organization.

Jeong et al. (2017) examined the effects of four dimensions of authentic leadership (self-awareness, relational transparency, balanced information processing, and an internalized 
moral perspective) on two trusts in leaders in the hospitality industry. The research results revealed that the three dimensions of authentic leadership have an impact on trust in leaders. Research by Levesque-Côté et al. (2018) provided additional support with positive associations between perceptions of authentic leadership and trust in leaders. Based on previous research, it can be concluded that authentic leadership can foster trust in leaders.

The low behavior of employee organizational citizenship behavior can also be caused by several factors, one of which is trust in leaders or the level of trust in leaders (Kartikarini, 2015). Trust is the hope that someone else's word, promise, or statement can be relied on (Poon et al., 2006). Trust is also defined as a psychological state that includes individual vulnerability based on positive predictions for the attention of others (Dirks \& Ferrin, 2002). Mahdi (2008) stated that trust in leaders is the attitude of a follower not to hesitate towards their leader ades and behavior (Hartog \& Hoogh, 2009). Wong et al. (2010) stated that trust arises through the continuous exchange of benefits between parties, which in turn affect employee work results. This is able to cause followers to improve organizational performance in order to achieve common goals and be able to improve OCB attitudes, followers' trust in their leader will make followers support future actions taken by the leader. Leadership and trust can be considered as social exchanges between leaders and followers (Hsieh \& Wang, 2015). Social exchange theory Blau (1964) revolves around the principle of reciprocity in which one party provides services to the other party and the other party develops a sense of obligation to reciprocate (Kashyap \& Rangnekar, 2014).

\section{LITERATURE REVIEW AND HYPOTHESIS DEVELOPMENT}

Previous research conducted by Walumbwa et al. (2010) found that authentic leadership has an impact on employee work outcomes, such as Organizational Citizenship Behaviors, commitment, and engagement. Tonkin (2013) conducted research on software companies in the United States, found that there was a positive correlation between the four dimensions of the authentic leadership dimension and Organizational Citizenship Behaviors using job satisfaction as a mediator. The results showed that authentic leadership has a positive effect on follower characteristics such as employee Organizational Citizenship Behaviors behavior and employee job satisfaction. Yeşilkaya \& Aydın (2016) also found a positive and significant relationship between perceived authentic leadership and Organizational Citizenship Behaviors in the Turkish public sector. Comparing authentic leadership and transformational leadership in the Metaalysis review, Banks et al. (2016) concluded that authentic leadership has a stronger relationship with Organizational Citizenship Behaviors. Wei et al. (2018) conducted research at a large Chinese company and reported that authentic leadership significantly predicted Organizational Citizenship Behaviors.

H1: Authentic leadership has a positive effect on organizational citizenship behavior.

A large number of empirical studies have investigated the effect of authentic leadership on trust in leaders and identified positive correlations between them (e.g. Clapp-Smith et al. (2009); Hassan \& Ahmed (2011); Peus et al. (2012); Wang \& Hsieh (2013); Wong \& Cummings (2009); Wong \& Giallonardo (2013). Jeong et al. (2017) examined the effects of four dimensions of authentic leadership (self-awareness, relational transparency, balanced information processing, and an internalized moral perspective) on trust in leaders in the hospitality industry. The research results reveal that the three dimensions of authentic leadership have an impact on trust in leaders. Research by Levesque-Côté et al. (2018) provides additional support with positive associations between perceptions of authentic leadership and trust in leaders. Research by Ceri-Booms (2010) also found that there was a positive relationship between authentic leadership and trust in leaders in Turkey. This study revealed that authentic leaders are very capable of fostering trust in employees.

$\mathrm{H} 2$ : Authentic leadership has a positive effect on trust in leaders. 
Trust in leaders is associated with positive followers' attitudes and behavior where there is a positive relationship between trust in leaders and OCB Hartog \& Hoogh (2009). Wong et al. (2010) stated that trust arises through the continuous exchange of benefits between parties, which in turn affect employee work results. This is able to cause followers to improve organizational performance in order to achieve common goals and be able to improve OCB attitudes; trust in leaders will make followers support future actions taken by their leaders. Leadership and trust can be considered as social exchanges between leaders and followers (Hsieh \& Wang, 2015). Social exchange theory Blau (1964) revolves around the principle of reciprocity in which one party provides services to the other party and the other party develops a sense of obligation to reciprocate (Kashyap \& Rangnekar, 2014). This positive relationship is further confirmed by a recent study conducted by Barzoki \& Rezaei (2017) which surveyed 158 employees at national oil and gas companies in Iran and found a positive relationship between trust in leaders and OCB.

H3: Trust in leaders has a positive effect on organizational citizenship behavior.

Min \& Ko (2016) studied 210 flight attendants and ground service employees of an airline in Korea. Although they did not identify a full or partial mediation effect of trust in leaders, their study clearly shows that authentic leadership has a significant impact on trust in leaders, and trust in leaders in turn has an impact on employee OCB. Qiu et al. (2019) conducted a study showing that authentic leadership behavior shown by leaders can generate trust in leaders which results in employees engaging in OCB behavior. Qiu et al. (2019) conducted a similar study in the hospitality sector, the results of this study also show that trust in leader function as a mediator between authentic leaders and $\mathrm{OCB}$, where authentic leaders instill their influence through trust in leaders to achieve high-level OCB behavior.

H4: Trust in leaders mediates the effect of authentic leadership on organizational citizenship behavior.

\section{METHODS}

The method used in this research is an associative quantitative method (relationship). This associative research is also used by Heider et al. (2015) in their research related to organizational citizenship behavior (OCB). The type of relationship in this study is a linear relationship because it aims to determine the variables that affect OCB.

The population in this study was 65 employees of Royal Tulip Springhill Resort Jimbaran regarding questionnaire statements about trust in leaders, authentic leadership, and OCB. The number of samples in this study was as many as 65 people with the distribution of positions as housekeeping, room service, bartender, waiter / waitress, front office, kitchen staff, security and so on. The method used in this research is the census method or saturated sampling technique.

Researchers provide a list of statements in the form of a questionnaire which will be distributed to respondents via google form where the previous data in ordinal form will be converted into intervals with the help of a Likert scale of 1 to 5 . The data analysis technique used in this study is the path analysis technique. The basis for calculating the path coefficient is correlation and regression analysis and the calculation uses software with the SPSS for windows program. 


\section{RESULTS AND DISCUSSION}

\section{Characteristics of Respondents}

Respondent characteristic data is respondent data collected to determine the profile of research respondents. Based on the results of research conducted on employees at the Royal Tulip Springhill Resort Jimbaran, it can be seen that the characteristics of the respondents include gender, age, and occupation which are described in Table 1.

Table 1. Characteristics of Respondents

\begin{tabular}{|c|c|c|c|c|}
\hline No & Variable & Classification & Total (Persons) & $\begin{array}{c}\text { Percentage } \\
(\%)\end{array}$ \\
\hline \multirow{3}{*}{1} & \multirow{2}{*}{ Gender } & Male & 20 & 30,77 \\
\hline & & Female & 45 & 69,23 \\
\hline & Total & & 65 & 100 \\
\hline \multirow{5}{*}{2} & \multirow{5}{*}{ Age } & $17-22$ years old & 20 & 30,77 \\
\hline & & $23-28$ years old & 25 & 38,46 \\
\hline & & 29- 33 years old & 14 & 21,54 \\
\hline & & 34-39 years old & 5 & 7,69 \\
\hline & & $\geq 40$ years old & 1 & 1,54 \\
\hline \multirow{5}{*}{3} & Total & & 65 & 100 \\
\hline & \multirow{4}{*}{$\begin{array}{l}\text { Education } \\
\text { Background }\end{array}$} & Senior High School & 38 & 58,46 \\
\hline & & Diploma & 20 & 30,77 \\
\hline & & Bachelor Degree & 6 & 9,23 \\
\hline & & Master Degree & 1 & 1,54 \\
\hline \multirow{7}{*}{4} & \multirow{6}{*}{ Job Experiences } & Total & 65 & 100 \\
\hline & & $<1$ year & 2 & 3,08 \\
\hline & & $1-3$ years & 30 & 46,15 \\
\hline & & 4-6 years & 18 & 27,69 \\
\hline & & 6-9 years & 10 & 15,38 \\
\hline & & $>9$ years & 5 & 7,69 \\
\hline & & & 65 & 100 \\
\hline
\end{tabular}

Source: Primary Data, 2020

Based on Table 1, it can be seen that the employees at the Royal Tulip Springhill Resort Jimbaran who were sampled were 65 people. When viewed from gender, female gender dominates in this study with a percentage of 69.23 percent. This indicates that female employees are more required to work at Royal Tulip Springhill Resort Jimbaran, because female employees are more conscientious than male employees. If we look at the age, those 23-28 years old dominate with a percentage of 38.46 percent. This indicates that 23-28 years old is a productive age and can support employee activities at Royal Tulip Springhill Resort Jimbaran. From education, those who have SMA / SMK education dominate with a percentage of 58.46 percent, this proves that the employees who work at Royal Tulip Springhill Resort Jimbaran are at least SMA / SMK education level employees where they have expertise in work. Judging from the occupation of respondents who have worked for 1-3 years dominating with a percentage of 46.15 percent, this proves that employees at Royal Tulip Springhill Resort Jimbaran have a fairly reliable working period in doing work and have considerable experience at work.

\section{Path Analysis}

This study uses path analysis techniques in seeing the effect of the causal relationship of each exogenous variable consisting of authentic leadership on endogenous variables consisting of trust in leaders and Organizational Citizenship Behaviors. This study also examines the role of the mediating variable, namely trust in leaders, in mediating the relationship between authentic leadership variables and Organizational Citizenship Behaviors.

In this study, the effect of authentic leadership on trust in leaders is calculated through the SPSS 21.0 for windows program. The following shows the results of the calculation of the first structure in Table 2. 
The Effect of Authentic Leadership on Organizational Citizenship Behaviors Mediated by Trust in Leaders

Table 2. Result of Path Analysis in Structure 1

\begin{tabular}{llcrrrr}
\hline \multirow{2}{*}{ Model } & \multicolumn{2}{c}{ Unstandardized Coefficients } & \multicolumn{2}{c}{ Standardized Coefficients } & \multirow{2}{*}{ S } & \multirow{2}{*}{ Sig. } \\
\cline { 2 - 4 } & $\mathrm{B}$ & Std. Error & Beta & & \\
\hline (Constant) & 0,823 & 0,270 & & 0,052 & 0,003 \\
Authentic leadership & 0,819 & 0,078 & & & 10,467 & 0,000 \\
\hline $\mathrm{R}^{2} \quad: 0,635$ & & & & & \\
\hline Primary Data, 2020 & & & & &
\end{tabular}

Based on the results of the path analysis in Table 2, the structural equation that is formed can be formulated as follows.

$$
\begin{gathered}
M=\beta 1 X+e 1 \\
M=0.797 X
\end{gathered}
$$

The variable authentic leadership has a coefficient of 0.797 , meaning authentic leadership has a positive effect on trust in leaders, this means that if authentic leadership increases, trust in leaders will increase by 0.797 .

In this study, the effect of authentic leadership and trust in leaders towards Organizational Citizenship Behaviors was calculated through the SPSS 21.0 for windows program. The following shows the results of the calculation of the second structure in Table 3.

\begin{tabular}{|c|c|c|c|c|c|}
\hline \multirow{2}{*}{ Model } & \multicolumn{2}{|c|}{ Unstandardized Coefficients } & \multirow{2}{*}{$\begin{array}{c}\text { Standardized } \\
\text { Coefficients }\end{array}$} & \multirow[t]{2}{*}{$\mathrm{t}$} & \multirow[t]{2}{*}{ Sig. } \\
\hline & B & Std. Error & & & \\
\hline (Constant) & 0,141 & 0,362 & & 0,390 & 0,698 \\
\hline Authentic leadership & 0,597 & 0,162 & 0,497 & 3,682 & 0,000 \\
\hline Trust in leaders & 0,361 & 0,138 & 0,309 & 2,289 & 0,025 \\
\hline
\end{tabular}

Table 3. The Result of Path Analysis in Structure 2

$\mathrm{R}^{2} \quad: 0,587$

Primary Data, 2020

Based on the results of the path analysis in Table 3, the structural equation that is formed can be formulated as follows.

$$
\begin{aligned}
& Y=\beta 2 X+\beta 3 M+e 2 \\
& Y=0.497 X+0.309 M
\end{aligned}
$$

The variable authentic leadership has a coefficient of 0.497 , meaning that authentic leadership has a positive effect on Organizational Citizenship Behaviors; this means that if authentic leadership increases, Organizational Citizenship Behaviors will increase by 0.497 . The trust in leader variable has a coefficient of 0.309 which means that trust in leaders has a positive effect on Organizational Citizenship Behaviors; this means that if trust in leaders increases, Organizational Citizenship Behaviors will increase by 0.309 .

\section{Determination Coefficient $\left(\mathbf{R}^{2}\right)$ and the Variable Error (e)}

This test will see the value of each coefficient of determination for structure 1 and structure 2 and the value of each error variable in each structure with the aim of compiling the final path diagram model. The following are the results of the calculation of the error variable values for each structure.

$$
\begin{aligned}
& \mathrm{e}_{\mathrm{i}}=\sqrt{1-\mathrm{R}_{\mathrm{i}}^{2}} \\
& \mathrm{e}_{1}=\sqrt{1-R_{1}^{2}}=\sqrt{1-0,635}=0,604
\end{aligned}
$$


$\mathrm{e}_{2}=\sqrt{1-R_{2}^{2}}=\sqrt{1-0,587}=0,643$

Calculation of the effect of error (e), the results for the effect of structural error 1 (e1) are 0.604 and the effect of structural error 2 (e2) is 0.643 . Then the total coefficient of determination will be calculated as follows:

$$
\begin{aligned}
\mathrm{R}^{2}{ }_{\mathrm{m}} & =1-\left(\mathrm{e}_{1}\right)^{2}\left(\mathrm{e}_{2}\right)^{2} \\
& =1-(0,604)^{2}(0,643)^{2} \\
& =1-(0,365)(0,413) \\
& =1-0,151=0,849
\end{aligned}
$$

The calculation of the total coefficient of determination is 0.849 , so the conclusion is that $84.9 \%$ of the Organizational Citizenship Behaviors variables at Royal Tulip Springhill Resort Jimbaran are influenced by authentic leadership, and trust in leaders, while the remaining $15.1 \%$ is influenced by other factors not included in the research model. or outside the research model.

Based on the explanation of structural equations, the results of the value of the path coefficient calculation are indicated by the standardized beta coefficient value for each effect of the relationship between variables.

\section{The Effect of Authentic Leadership on Organizational Citizenship Behavior}

Based on the results in Table 3 authentic leadership has a beta value of 0.497 and a Sig. amounting to 0,000 , it can be said that $\mathrm{Ha}$ is accepted because of the Sig. $0.000<0.05$. The conclusion is that authentic leadership has a partial effect on OCB, in other words, the more authentic leadership increases, the more OCB increases at Royal Tulip Springhill Resort Jimbaran, so that the first hypothesis is accepted.

The results of the hypothesis in this study indicate that authentic leadership has a positive and significant effect on OCB, in other words, the more authentic leadership increases, the OCB at Royal Tulip Springhill Resort Jimbaran will increase. Hence, the first hypothesis is accepted. Based on the theory of social exchange, if the leader in a company has good character and attitude in leading it will provide a good view for employees, by increasing OCB. Previous research conducted by Walumbwa et al. (2010) found that authentic leadership has an impact on employee work outcomes, such as OCB, commitment, and engagement.

Tonkin (2013) conducted research on software companies in the United States, found that there was a positive correlation between the four dimensions of the authentic leadership dimension and OCB using job satisfaction as a mediator. The results showed that authentic leadership has a positive effect on follower characteristics such as employee OCB behavior and employee job satisfaction.

Yeşilkaya \& Aydın (2016) also found a positive and significant relationship between perceived authentic leadership and OCB in the Turkish public sector. Comparing authentic leadership and transformational leadership in a meta-analysis review, Banks et al. (2016) concluded that authentic leadership has a stronger relationship with OCB. Wei et al. (2018) conducted research at a large Chinese company and reported that authentic leadership significantly predicted OCB.

\section{The Effect of Authentic Leadership on Trust in Leaders}

Based on the results in Table 2 authentic leadership has a beta value of 0.797 and a Sig. amounting to 0,000 , it can be said that $\mathrm{Ha}$ is accepted because of the Sig. $0.000<0.05$. The conclusion is that authentic leadership has a partial effect on trust in leaders, in other words, the increased authentic leadership at Royal Tulip Springhill Resort Jimbaran, the more trust in leaders will increase at Royal Tulip Springhill Resort Jimbaran, so that the second hypothesis is accepted. 

in Leaders

The results of the hypothesis in this study indicate that authentic leadership has a positive and significant effect on trust in leaders, in other words, the increasing authentic leadership at Royal Tulip Springhill Resort Jimbaran, the higher the level of trust in leaders at Royal Tulip Springhill Resort Jimbaran. Hence the second hypothesis is accepted.

Based on the theory of social exchange, if a leader in a company has good characteristics and attitudes in leading, this will give employees confidence in their superiors, where the social exchange theory looks at behavior and the environment on interplay of relationships (Syam, 2012), a large number of empirical research have investigated the effect of authentic leadership on trust in leaders and identified a positive correlation between them (e.g. Clapp-Smith et al. (2009); Hassan \& Ahmed (2011); Peus et al. (2012); Wang \& Hsieh (2013); Wong \& Cummings (2009) ; Wong \& Giallonardo (2013). Jeong et al. (2017) examined the effects of four dimensions of authentic leadership (self-awareness, relational transparency, balanced information processing, and an internalized moral perspective) on trust in leaders in the hospitality industry. The research results reveal that the three dimensions of authentic leadership have an impact on trust in leaders. Research by Levesque-Côté et al. (2018) provides additional support with positive associations between perceptions of authentic leadership and trust in leaders. Research by Ceri-Booms (2010) also found that there was a positive relationship between authentic leadership and trust in leaders in Turkey. This study revealed that authentic leaders are very capable of fostering trust in employees.

\section{The Effect of Trust in Leaders on Organizational Citizenship Behavior}

Based on the results in Table 3, trust in leaders has a beta value of 0.309 and a Sig. amounting to 0.025 , it can be said that $\mathrm{Ha}$ is accepted because of the Sig. $0.025<0.05$. The conclusion is that trust in leaders has a partial effect on organizational citizenship behavior, in other words if trust in leaders increases, then OCB at Royal Tulip Springhill Resort Jimbaran will increase. Hence the third hypothesis is accepted.

The results of the hypothesis in this study indicate that trust in leaders has a positive and significant influence on OCB. In other words, if trust in leaders increases then OCB at Royal Tulip Springhill Resort Jimbaran will increase so that the third hypothesis is accepted. Based on the social exchange theory, if employees have increased employee trust in their superiors, this will make employees feel loyal to the company so that it will increase the OCB owned by employees.

Dirks \& Ferrin (2002) stated that trust in leaders has a positive impact on employee commitment and OCB. These authors assert that the behavior and characteristics of leaders influence how followers build trust. Followers will return the favor by doing additional tasks above and beyond their routine work to help others (Poon et al., 2006). Liu et al. (2013) studied the hospitality industry in Taiwan, and they reported that there is a positive and significant relationship between trust in leaders and OCB. This positive relationship is further confirmed by a recent study conducted by Barzoki \& Rezaei (2017) which surveyed 158 employees at national oil and gas companies in Iran and found a positive relationship between trust in leaders and OCB.

\section{Sobel test}

The Sobel test is an analytical tool to test the significance of the indirect relationship between the independent variable and the dependent variable which is mediated by the mediator variable. The Sobel test is formulated with the following equation and can be calculated using the Microsoft Excel 2010 application. If the $\mathrm{Z}$ calculation value is greater than 1.96 (with a confidence level of $95 \%$ ), then the mediator variable is considered to significantly mediate the relationship between the dependent variable and the independent variable. 


$$
\begin{aligned}
& \mathrm{Z}=\frac{\mathrm{ab}}{\sqrt{\mathrm{b}^{2} \mathrm{~S}_{\mathrm{a}}^{2}+\mathrm{a}^{2} \mathrm{~S}_{\mathrm{b}}^{2}+\mathrm{S}_{\mathrm{a}}^{2} \mathrm{~S}_{\mathrm{b}}^{2}}} \ldots \ldots \ldots \ldots \ldots \ldots \ldots \ldots(2) \\
& \text { Keterangan: } \\
& \mathrm{a}=0,797 \\
& \begin{array}{l}
\mathrm{S}_{\mathrm{a}}=0,078 \\
\mathrm{~b}=0,309
\end{array} \\
& \quad \mathrm{~S}_{\mathrm{b}}=0,138 \\
& \quad Z=\frac{0,797.0,309}{\sqrt{\left(0,309^{2} 0,078^{2}\right)+\left(0,797^{2} 0,138^{2}\right)+\left(0,078^{2} 0,138^{2}\right)}} \\
& Z=\frac{0,246}{0,113} \\
& Z=2,177
\end{aligned}
$$

\section{The Effect of Authentic Leadership on Organizational Citizenship Behavior by Mediating Trust in Leaders}

Based on the results of the sobel test, it shows that the tabulation results $Z=2.177>1.96$, which means that the authentic leadership variable has a positive and significant effect on organizational citizenship behavior at Royal Tulip Springhill Resort Jimbaran by mediating trust in leaders, so that trust in leaders is a mediating variable of influence between authentic leadership towards organizational citizenship behavior at Royal Tulip Springhill Resort Jimbaran, therefore the fourth hypothesis is accepted.

The results of the hypothesis in this study indicate that authentic leadership has a positive and significant effect on OCB at Royal Tulip Springhill Resort Jimbaran by mediating trust in leaders, so that trust in leaders is a mediating variable for the influence of authentic leadership on OCB. Hence, the fourth hypothesis is accepted. Based on the theory of social exchange, if the leader in a company has good characteristics and attitudes in leading, this will give employees confidence, increase in their superiors and this will make employees feel loyal to the company so that it will increase the OCB owned by employees.

Min \& Ko (2016) studied 210 flight attendants and ground service employees of an airline in Korea. Although they did not identify a full or partial mediation effect of trust in leaders, their study clearly shows that authentic leadership has a significant impact on trust in leaders, and trust in leaders in turn has an impact on employee OCB. Qiu et al. (2019) conducted a study showing that authentic leadership behavior shown by leaders can generate trust in leaders which results in employees engaging in OCB behavior. Shaoping Qiu et al. (2019) conducted a similar study in the hospitality sector, the results of this study also show that trust in leaders function as a mediator between authentic leaders and OCB, where authentic leaders instill their influence through trust in leaders to achieve high-level OCB behavior.

\section{CONCLUSION}

Social exchange theory states that with trust in leaders, authentic leadership can have an effect on Organizational Citizenship Behaviors. Therefore, with better authentic leadership, trust in leaders will increase and will also increase employee Organizational Citizenship Behaviors. In addition, the results of this research can practically be a reference for other researchers who want to research on authentic leadership, trust in leaders and Organizational Citizenship Behaviors. Theoretically, this research also provides an understanding that authentic leadership and trust in leaders can actually improve Organizational Citizenship Behaviors, when increased authentic leadership is obtained by increasing trust in leaders, the trust in leaders felt by 
The Effect of Authentic Leadership on Organizational Citizenship Behaviors Mediated by Trust in Leaders

employees will become stronger, thus potentially increasing Organizational Citizenship Behaviors.

For further research, it is hoped that it will be able to add variables that can affect Organizational Citizenship Behaviors, and be able to expand the scope of research that is not only limited to the Royal Tulip Springhill Resort Jimbaran, or can also replace the research location that is not only focused on a research location, thus providing a more views and can be implemented in general.

\section{REFERENCES}

Agote, L., Aramburu, N., \& Lines, R. (2016). Authentic leadership perception, trust in leader, and followers' emotions in organizational change processes. J. Appl. Behav. Sci, 52, 35-63.

Avolio, B. J., \& Walumbwa, F. O. (2014). Authentic leadership theory, research and practice:steps taken and steps that remain. Oxford University Press.

Bambale, A. J. (2014). Relation between Servant Leadership and Organizational Citizenship Behaviors: Review of Literature and Future Research Directions. Journal of Marketing and Management, 5(1), 1-16.

Bamford, M., Wong, C. A., \& Laschinger, H. (2013). The influence of authentic leadership and are as of work life on work engagement of register ednurses. Journal of Nursing Management, 21, 529-540.

Banks, G. C., Mc Cauley, K. D., Gardner, W. L., \& Guler, C. E. (2016). Ameta analytic review of authentic and transformational leadership: Ates for redundancy. The Leadership Quarterly, 27(4), 634-652.

Barzoki, A. S., \& Rezaei, A. (2017). Relationship between perceived organisational support, organisational citizenship behaviour, organisational trust and turnover intentions: an empirical case study. International Journal of Productivity and Quality Management, 21(3), 273-299.

Bhindi, N., Riley, D., Smith, R., \& Hansen, J. (2008). Authentic leadership in education: A cross-country reality.

Blau. (1964). Exchange and Power in Social Life (T. Publishers (ed.)).

Ceri-Booms, M. (2010). An empirical study on transactional and authentic leaders: Exploring the mediating role of trust in leader on organizational identification. Business Review, Cambridge Journal.

Clapp-Smith, R., Vogelgesang, G. R., \& Avey, J. B. (2009). Authentic Leadership and Positive Psychological CapitalThe Mediating Role of Trust at the Group Level of Analysis. Journal of Leadership \& Organizational Studies, 15(3), 227-240. https://doi.org/10.1177/1548051808326596

Dirks, K. T., \& Ferrin, D. L. (2002). Trust in leadership: Meta-analytic findings and implications for research and practice. Journal of Applied Psychology, 87(4), 611-628. https://doi.org/1037/0021-9010.87.4.611

Fung, N. S., Ahmad, A., \& Omar, Z. (2012). Work-family Enrichment: It's Mediating Role In The Relationship between Dispositional Factors and Job Satisfaction. International Journal Og Academic Research in Business and Social Sciences, 2(11), 11-88.

Gardner, W. L., Avolio, B. J., Luthans, F., May, D. R., \& Walumbwa, F. (2005). Can you see the real me? Aself-based model of authentic leader and follower development. The Leadership Quarterly, 16(3), 343-372. 
Hartog, D. N. Den, \& Hoogh, A. H. B. De. (2009). Empowerment and Leader Fairness and Integrity: Studying Ethical Leader Behavior. European Journal of Work and Organizational Psychology, 18, 199-230.

Hassan, A., \& Ahmed, F. (2011). Authentic leadership, trust and work engagement. International Journal of Social, Behavioral, Educational, Economic, Business and Industrial Engineering, 5(8), 1036-1042.

Heider, N., Spruyt, A., \& Houwer, J. De. (2015). Implicit Beliefs about Ideal Body Image Predict Body Image Dissatisfaction. Frontiers in Psychology, 6, 1402(319). https://doi.org/10.3389/fpsyg.2015.01402

Hsieh, C.-C., \& Wang, D.-S. (2015). Does supervisor-perceived authentic leadership influence employee work engagement through employee-perceived authentic leadership and employee trust? International Journal of Human Resource Management, 26(18), 1-20.

Jeong, Y.-K., Lee, Y.-K., \& Kim, S. Y. (2017). To be true or not to be true: authentic leadership and its effect on travel agents. Asia Pacific Journal of Tourism Research. https://doi.org/10.1080/10941665.2017.1331921

Kartikarini, M. (2015). Pengaruh Servant Leadership Dan Kepuasan Kerja Terhadap Organizational Citizenship Behaviour Karyawan Hotel Bintang-2 Di Yogyakarta. Universitas Negeri Yogyakarta.

Kashyap, V., \& Rangnekar, S. (2014). Servant leadership, employer brand perception, trust in leaders and turnover intentions: a sequential mediation model. Review of Managerial Science, 10(3). https://doi.org/10.1007/s11846-014-0152-6

Levesque-Côté, J., Fernet, C., Austin, S., \& Morin, A. J. S. (2018). New Wine in a New Bottle: Refining The Assessment of Authentic Leadership Using Exploratory Structural Equation Modeling (ESEM). Journal of Business and Psychology, 33(7), 1-18. https://doi.org/10.1007/s10869-017-9512-y

Liu, S., Lin, X., \& Hu, W. (2013). How followers' unethical behavior is triggered by leadermember exchange: The mediating effect of job satisfaction. Social Behavior and Personality. An International Journal, 41(3), 357-366.

Mahdi, I. (2008). eterkaitan antara KeadilanOrganisasional, Kepercayaan Terhadap Atasandan Perilaku Kewargaan Organisasi: StudiKasus pada Pengelola Program Studi PerguruanTinggi Negeri (PTN) dan Perguruan TinggiSwasta (PTS) di Daerah Surakarta. Jurnal Perspektif Ekonomi, 1(2), 149-166.

Min, P. J., \& Ko, S. H. (2016). The Structutal Relationship among Authentic Leadership, Trust in Supervisor, Innovative Behavior and Organizational Citizenship Behavior. Journal of Science and Technology, 9(25). https://doi.org/10.17485/ijst/2016/v9i25/97264

Organ, D. (1997). Organizational Citizenship Behavior: It's Construct Clean-Up Time. Human Performance, 10(2), 85-97. https://doi.org/10.1207/s15327043hup1002_2

Peus, C., Wesche, J. S., Streicher, B., Braun, S., \& Frey, D. (2012). Authentic leadership: An empirical test of its antecedents, consequences, and mediating mechanisms. Journal of Business Ethics, 107(3), 331-348.

Podsakoff, P. M., MacKenzie, S. B., Paine, J. B., \& Bachrach, D. G. (2000). Organizational Citizenship Behavior : Critical Review of The Theoretical and Empirical Literature and Suggestions for Future Research. Journal of Management, 26(3), 513-563. 
The Effect of Authentic Leadership on Organizational Citizenship Behaviors Mediated by Trust in Leaders

Poon, J. M. L., Junit, R. A. A., \& Haji, S. (2006). Effects of Self-Concept Traits and Entrepreneurial Orientation on Firm Performance. International Small Business Journal, 24(1), 61-82. https://doi.org/10.1177/0266242606059779

Qiu, S., Alizadeh, A., Dooley, L. M., \& M., Z. (2019). The effects of authentic leadership on trust in leaders, organizational citizenship behavior, and service quality in the Chinese hospitality industry. Journal of Hospitality and Tourism Management, 40, 77-84. https://doi.org/10.1016/j.jhtm.2019.06.004

Qiu, Shaoping, Alizadeh, A., Dooley, L., \& Zhang, R. (2019). The effects of authentic leadership on trust in leaders, organizational citizenship behavior, and service quality in the Chinese hospitality industry. Journal of Hospitality and Tourism Management, 40, 77-87. https://doi.org/10.1016/j.jhtm.2019.06.004

Shin, Y., Kim, M. S., Choi, J. N., Kim, M., \& Oh, W. K. (2017). Does leader-follower regulatory fit matter? The role of regulatory fit in followers' organizational citizenship behavior. Journal of Management, 43(4), 1211-1233.

Sosik, J. J., \& Jung, D. (2018). Full Range Leadership Development Pathways for People, Profit, and Planet (2nd ed.). Routledge. https://doi.org/10.4324/9781315167206

Syam, N. W. (2012). Psikologi Sebagai Akar Ilmu Konumikasi. Simbiosa Rekatama Media.

Tonkin, T. (2013). Authentic versus transformational leadership: Assessing their effectiveness on organizational citizenship behavior of followers. International Journal of Business and Public Administration, 10.

Walumbwa, F. O., Wang, P., Wang, H., \& Schaubroeck, J. (2010). Psychological processes linking authentic leadership to follower behaviors. The Leadership Quarterly, 21(5), 901914. https://doi.org/10.1016/j.leaqua.2010.07.015

Wang, D.-S., \& Hsieh, C.-C. (2013). The effect of authentic leadership on employee trust and employee engagement. Social Behavior and Personality: An International Journal, 41(4), 613-624. https://doi.org/0.2224/sbp.2013.41.4.613

Wei, F., Li, Y., Zhang, Y., \& Liu, S. (2018). The interactive effect of authentic leadership and leader competency on followers' job performance: The mediating role of work engagement. Journal Lof Business Ethics, 153(3), 763-773.

Wong, C. A., \& Cummings, G. G. (2009). The influence of authentic leadership behaviors on trust and work outcomes of health care staff. Journal of Leadership Studies, 3(2), 6-23. https://doi.org/10.1002/jls.20104

Wong, C. A., \& Giallonardo, L. M. (2013). Authentic leadership and nurse-assessed adverse patient outcomes. J Nurs Manag, 21(5), 740-752. https://doi.org/10.1111/jonm.12075

Wong, C. A., Spence-Laschinger, H. K., \& Cummings, G. . (2010). Authentic leadership and nurses' voice behaviour and perceptions of care quality. Journal of Nursing Management, $18,889-900$.

Yeşilkaya, M., \& Aydın, P. (2016). Do Employees' Perceptions on Authentic Leadership Affect the Organizational Citizenship Behavior? : Turkish Context. International Journal of Leadership in Education, 6(1), 1-13. 